\title{
C-Reactive Protein and Matrix Metalloproteinase-9 are Associated with Outcome of Ischemic Stroke
}

\author{
Yenny Surjawan ${ }^{1 *}$, Suryani As'ad ${ }^{1}$, Teguh A.S. Ranakusuma ${ }^{2}$, Andi Wijaya ${ }^{1,3}$ \\ ${ }^{1}$ Ph.D Program, Faculty of Medicine, Hasanuddin University, Jl. Perintis Kemerdekaan Km.10. Makassar, Indonesia \\ ${ }^{2}$ Department of Neurology, Faculty of Medicine, JI. Salemba Raya No.4, Jakarta, Indonesia \\ ${ }^{3}$ Prodia Clinical Laboratory, Jl. Cisangkuy No. 2 Bandung, Indonesia \\ ${ }^{*}$ Correspondence: Prodia Clinical Laboratory, Jl. Kramat Raya 150, Jakarta, Indonesia \\ e-mail: yensurjawan@yahoo.com
}

\section{Abstract}

$\mathrm{B}$

ACKGROUND: C-Reactive protein (CRP) and matrix metalloproteinase (MMP)-9 are inflammatory mediators that are often associated with the evolution of stroke. In this study, we aimed to find out whether concentration of these biomarkes were associated with the severity of discharge NIHSS (National Institute of Health Stroke Scale) in ischemic stroke patient.

METHODS: In a prospective study, we involved 143 ischemic stroke patients who were admitted to hospital not more than 72 hours after the onset and who met the criteria. The concentration of CRP was assessed by High Sensitivity CRP reagent from Siemens (Cat. L2KCRP6) and the concentration of MMP-9 was measured with Quantikine Human MMP-9 (total) Immunoassay from R\&D (Cat. DMP900). The outcome of stroke was determined by NIHSS score at discharge.

RESULTS: There was a significant correlation between the CRP level and the severity of NIHSS at discharge $(r=$ $0.288, p=0.000$ ). Subjects with intermediate/ high level of CRP had a higher probability to have a moderate or even severe NIHSS $(\mathrm{OR}=2.7, \mathrm{p}=0.004)$. Subjects with high MMP level showed a higher probability to have a severe NIHSS.

\section{Abstrak}

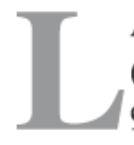

ATAR BELAKANG: C-Reactive protein (CRP) dan matrix metalloproteinase (MMP)9 merupakan mediator inflamasi yang sering dihubungkan dengan perkembangan stroke. Penelitian ini ingin mengetahui apakah kadar kedua biomarker ini berhubungan dengan NIHSS (National Institute of Health Stroke Scale) pasien stroke iskemik saat akhir perawatan.

METODA: Penelitian dilakukan secara prospektif terhadap 143 pasien stroke iskemik yang datang ke rumah sakit tidak lebih dari 72 jam sejak onset dan memenuhi kriteria penelitian. Kadar CRP diperiksa dengan menggunakan reagen High Sensitivity CRP dari Siemens (Cat. L2KCRP6). Kadar MMP-9 diperiksa dengan menggunakan reagen Quantikine Human MMP-9 (total) Immunoassay dari R\&D (Cat. DMP900). Outcome stroke dinilai dengan skor NIHSS saat akhir perawatan di rumah sakit.

HASIL: Ada hubungan bermakna antara tinggi rendahnya CRP dengan berat ringannya NIHSS akhir $(\mathrm{r}=0.288, \mathrm{p}=$ 0.000). Subjek dengan kadar CRP sedang/ tinggi memiliki kemungkinan lebih besar untuk menunjukan NIHSS sedang atau bahkan berat $(\mathrm{OR}=2.7, \mathrm{p}=0.004)$. Subjek dengan kadar MMP-9 tinggi menunjukan kemungkinan lebih besar untuk memiliki NIHSS berat. 
CONCLUSION: The measurement of CRP and MMP9 at 48-72 hours after stroke onset were associated with the severity of ischemic stroke based on NIHSS score at discharge.

KEYWORDS: inflammation, CRP, MMP-9, discharged NIHSS

Indones Biomed J 2012; 4 (3): 157-163
KESIMPULAN: Pemeriksaan CRP dan MMP-9 antara 48-72 jam setelah onset stroke dapat menggambarkan inflamasi yang dihubungkan dengan beratnya NIHSS saat pulang.

KATA KUNCI: inflamasi, CRP, MMP-9, skor NIHSS saat akhir perawatan di rumah sakit

Indones Biomed J 2012; 4 (3): 157-163

\section{Introduction}

Inflammation that is involved in ischemia cascade plays an important role in the course of stroke (1). Initially the inflammation is directed to clear the debris and apoptotic cells in the ischemic brain, but it can turn out to aggravate the existing tissue damage (2).

Many proinflammatory mediators are produced during the brain ischemia (1). This mediators immediately induces the synthesis of C-Reactive protein (CRP) in the liver (3). The concentration of CRP was higher in subjects with more severe neurological deficit that was measured by NIHSS (National Institute of Health Stroke Scale) $(4,5)$. The proinflammatory mediators also stimulates the synthesis of matrix metalloproteinase (MMP)-9 (6) a marker of inflammation associated with blood brain barrier disruption (7) and shows a high association with stroke $(\mathrm{p}<0.001)(8,9)$.

In this study we want to know whether both of these biomarkers are associated with the severity of neurological deficit in ischemic stroke patient, when they leave hospital based on NIHSS score.

\section{Methods}

This was an observational study performed on 143 patients with anterior circulation ischemic stroke who were admitted to hospital not more than 72 hours after the onset. Subjects were enrolled from several hospitals in Jakarta and Makassar from June 2011 until December 2012. The diagnosis of anterior circulation ischemic stroke was made by the neurologists based on the history or anamnesis, physical examination, and CT/ MRI. This study was approved by the Health and Research Ethics Committee, Medical Faculty of Hasanuddin University, Makassar, Indonesia.

On obtaining their informed consents, the stroke patients who had their first attacks and received a standard medical care were included in this study. Patients who had liver dysfunction (female: AST > 54 U/L, ALT > $68 \mathrm{U} / \mathrm{L}$; male: AST > $66 \mathrm{U} / \mathrm{L}$, ALT $>100 \mathrm{U} / \mathrm{L}$ ), serum creatinine $>1.6 \mathrm{mg} / \mathrm{dL}[141.44 \mu \mathrm{mol} / \mathrm{L}]$, random blood glucose < $55 \mathrm{mg} / \mathrm{dL}$ [3.0525 mmol/L], systolic blood pressure $<100$ $\mathrm{mmHg}$ or diastolic blood pressure $<70 \mathrm{mmHg}$, and history of cancer, acute myocardial infarction, or congestive heart disease within the last 3 months, were excluded from the study.

Blood was collected between 48 and 72 hours after the onset of stroke in serum separation tubes (SST) for MMP-9 measurement, and in clot activator tubes for CRP measurement. The plasma SST and the serum were kept at $<20^{\circ} \mathrm{C}$ until all samples were ready to be analyzed and the diagnosis of anterior circulation ischemic stroke was confirmed. The concentration of CRP was measured with immunochemiluminescent method using Immulite 2000 High Sensitivity CRP from Siemens (Cat. L2KCRP6) and the result was reported in $\mathrm{mg} / \mathrm{L}$. The concentration of MMP-9 was measured with ELISA method using Quantikine Human MMP-9 (total) Immunoassay reagent from R\&D (Cat. DMP900) and the result was reported in $\mathrm{ng} / \mathrm{mL}$. The assays were done at the Research Department of Prodia Clinical Laboratory, Jakarta, Indonesia.

Stroke outcomes were recorded when the patients were discharged from hospital. Patients who survived were assessed for their NIHSS by a trained assistant or neurologist. The results were noted on a range from 0 , as the minimal score, to 42 , as the maximal score. The NIHSS was classified as mild, moderate and severe if the score was less than 4,4 to 15 , and more than 15 , 
respectively. Non-surviving patients were considered to have the maximum score of NIHSS.

Data was analysed using SPSS 16.0 statistical analysis software for Windows (SPSS Inc., Chicago, IL, USA). The significant level of this analysis was set at 0.05 .

\section{Results}

This study involved 143 subjects who fulfilled the criteria, consisted of male and female subjects aged from 30 to 85 years old (Table 1). At discharge, there were 52.4 $\%$ subjects with mild NIHSS and $44.1 \%$ subjects with moderate NIHSS. Only $3.5 \%$ of the subjects had severe NIHSS, who all died.
The result of the biomarkers did not show a normal distribution data (Kolmogorov Smirnov test, $\mathrm{p}<0.05$ ), therefore the data were analyzed by non parametric analysis.

The concentration of CRP and MMP-9 was significantly different among NIHSS groups (Kruskal Wallis test, $\mathrm{p}<0.05)$. Further post hoc analysis using Mann Whitney test showed a significant difference in CRP concentration among subjects with mild, moderate, and severe NIHSS $(\mathrm{p}<0.05)$. A significant difference in MMP-9 concentration was also found between subjects with severe and non severe (mild-moderate) NIHSS ( $p<$ 0.05) (Table 2, Figure 1).

Table 1. Baseline characeristic of the subjects $(N=143)$

\begin{tabular}{lr}
\hline \multicolumn{1}{c}{ Variable } & N (\%) \\
\hline Age (year) & \\
$30-44$ & $15(10.5)$ \\
$45-64$ & $93(65.0)$ \\
$65-85$ & $35(24.5)$ \\
Gender & \\
Male & $83(58.0)$ \\
Female & $60(42.0)$ \\
Discharged NIHSS & \\
Mild (score 0-3) & $75(52.4)$ \\
Moderate (score 4-15) & $63(44.1)$ \\
Severe (score 16-42) & $5(3.5)$ \\
\hline
\end{tabular}

Table 2. The median concentration of biormarker according to the NIHSS classification

\begin{tabular}{lccc}
\hline Variable & $\begin{array}{c}\text { Mild NIHSS } \\
(\mathbf{N}=\mathbf{7 5})\end{array}$ & $\begin{array}{c}\text { Moderate NIHSS } \\
(\mathbf{N}=\mathbf{6 3})\end{array}$ & $\begin{array}{c}\text { Severe NIHSS } \\
(\mathbf{N}=\mathbf{5})\end{array}$ \\
\hline CRP $(\mathrm{mg} / \mathrm{l})$ & 5.02 & 10.40 & 33.80 \\
MMP-9 $(\mathrm{ng} / \mathrm{ml})$ & 741.08 & 795.03 & 2534.30 \\
\hline
\end{tabular}



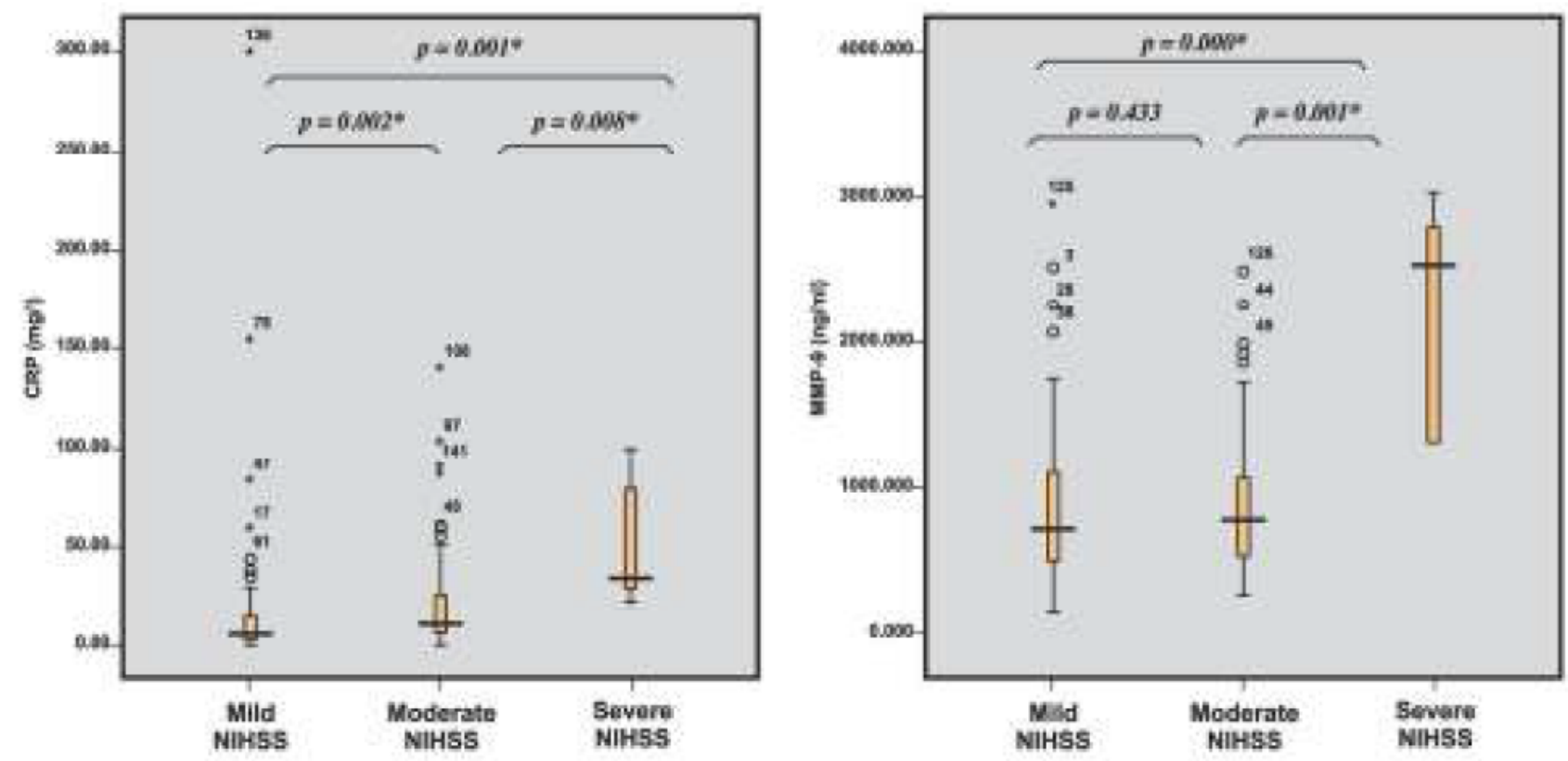

Figure 1. The difference concentration of CRP and MMP-9 among mild, moderate, and severe NIHSS.

The low cutoff values of CRP and MMP-9 were determined with receiver operating characteristics (ROC) curve to differentiate between subjects with non mild and mild NIHSS; the high cutoff value of CRP and MMP-9 were also determined to differentiate between subjects with severe and non severe NIHSS. The concentration of each biomarker was classified into 3 levels: high if the concentration was higher or equal to the high cutoff value, low if the concentration was lower than the low cutoff value, and intermediate if the concentration was in between both of those cutoff values (Table 3 ).

These cutoff values (Table 3) was used to tabulate the subjects with high, intermediate, and low level of biomarkers in subjects with severe, moderate, and mild
NIHSS as shown in Table 4. The Spearman correlation test showed that there was a significant correlation between the CRP level and the severity of NIHSS $(r=0.288, p$ $=0.000)$, but the MMP-9 did not show any significant correlation.

Chi-square analysis showed that subjects with intermediate and high CRP concentration had a higher probability to have a non-mild NIHSS $(\mathrm{OR}=2.7, \mathrm{p}=$ 0.004). Even subjects with high CRP level showed a higher probability to have a severe NIHSS. No association was shown between low and intermediate MMP-9 level with NIHSS, but subjects with high level of MMP-9 showed a higher probability to have a severe NIHSS (Table 5).

Table 3. The cut off value of biormarker according to the NIHSS

\begin{tabular}{lcccccc}
\hline \multirow{2}{*}{ Biomarker } & \multicolumn{3}{c}{ Non mild vsMild NIHSS } & \multicolumn{3}{c}{ Severe vs NonSevere NIHSS } \\
& Low cut off & Sensitivity & Specivicity & Low cut off & Sensitivity & Specivicity \\
\hline CRP(mg/l) & 8.60 & 61.8 & 62.7 & 25.65 & 80.0 & 81.2 \\
MMP-9 $(\mathrm{ng} / \mathrm{ml})$ & 789.80 & 54.4 & 53.3 & 1323.84 & 80.0 & 81.9 \\
\hline
\end{tabular}


Table 4. The crosstabulation and the correlation of biomarker level and NIHSS

\begin{tabular}{lccccc}
\hline Biomarker & Severe & Moderate & Mild & $\boldsymbol{r}$ & $\boldsymbol{p}$ \\
\hline CRP & & & & & \\
High $(>=25.65 \mathrm{mg} / \mathrm{l})$ & 4 & 16 & 16 & & \\
Intermediate $(8.6-25.65 \mathrm{mg} / \mathrm{l})$ & 1 & 21 & 21 & 0.288 & $0.000^{*}$ \\
Low $(<8.6 \mathrm{mg} / \mathrm{l})$ & 0 & 26 & 26 & & \\
MMP-9 & & & & & \\
$\quad$ High $(>=1323.84 \mathrm{ng} / \mathrm{ml})$ & 4 & 14 & 11 & & $0.070^{*}$ \\
Intermediate $(789.80-1323.83 \mathrm{ng} / \mathrm{ml})$ & 1 & 18 & 24 & 0.152 & \\
$\quad$ Low $(<789.80 \mathrm{ng} / \mathrm{ml})$ & 0 & 31 & 40 & & \\
\hline
\end{tabular}

*Spearman correlation test, $p<0.05$.

\section{Table 5. The influence of biomarker level on the severity of NIHSS}

\begin{tabular}{|c|c|c|c|c|c|c|}
\hline \multirow{2}{*}{ Biomarker level } & \multicolumn{3}{|c|}{ Non mild NIHSS } & \multicolumn{3}{|c|}{ Severe NIHSS } \\
\hline & OR & $95 \% \mathrm{Cl}$ & $p$ & OR & $95 \% \mathrm{Cl}$ & $p$ \\
\hline \multicolumn{7}{|l|}{ CRP } \\
\hline Intermediate \& High & 2.7 & $1.4-5.3$ & $0.004^{\star}$ & - & - & - \\
\hline High & - & - & - & 17.2 & $1.9-160.6$ & $0.007^{*}$ \\
\hline \multicolumn{7}{|l|}{ MMP-9 } \\
\hline Intermediate \& High & 1.4 & $0.7-2.6$ & 0.404 & - & - & - \\
\hline High & - & - & - & 18.1 & $1.9-168.8$ & $0.006^{*}$ \\
\hline
\end{tabular}

${ }^{\star}$ Chi-square test, $\mathrm{p}<0.05$

\section{Discussion}

The occlusion of cerebral blood flow in ischemic stroke reduces the energy supply that is required for normal metabolism of brain cells. The ischemic brain cells are unable to control the passage of ions through the cell membranes and cause intracellular accumulation of calcium ion $(2,10,11)$.

Accumulation of calcium ion induces the initiation of inflammation $(10,11)$. The ischemic brain cells produces several proinflammatory cytokines (IL- $1 \beta, \mathrm{IL}-6, \mathrm{TNF}-\alpha)$, chemokines, and reactive oxygen species (ROS) that lead to the activation of glial cells. This activated glial cells produces a more prominent proinflammatory mediators and increase the expression of adhession molecules on the surface of vascular endhotelial (1). This process is followed by the infitration of leukocytes into ischemic area (12).

In brain ischemia, phagocytosis by microglia is the main mechanism to eliminate the debris and apoptotic cells. This secondary activation of microglia that was caused by tissue damage will cause a release of free radicals into the surrounding environment of the neuron and result in an oxidative injury (13). Secondary injury of the surrounding tissue that is still viable will result in cell 
death $(1,14)$. This process will exacerbate the damage and cause a permanent cerebral damage (2).

In this study, the association of inflammation and the severity of neurological deficit at discharge was evaluated by measuring the concentration of CRP and MMP-9 as inflammation markers and by assessing NIHSS as a tool to measure the severity of neurological deficit. The baseline characteristics of the subjects are shown in Table 1.

This study showed that the median concentration of CRP was significantly higher in accordance with the severity of neurological deficit at discharge. The highest median concentration was found in subjects with severe NIHSS, a lower concentration was found in subjects having moderate NIHSS, and the lowest was found in subjects with mild NIHSS (Table 2, Figure 1). The result of this study was agreeable with the results of other studies that showed the risk of mortality or stroke reccurence was higher in subjects with higher CRP concentration $(15,16)$.

As shown in Table 3, the subjects were classified into high, intermediate, and low concentration of biomarkers according to the severity of NIHSS classification (Table 4). Spearman correlation test showed that there was a weak, but significant positive correlation between the CRP level and the severity of NIHSS. The bivariate analysis (chisquare test) showed that subjects with CRP concentration $>8.6 \mathrm{mg} / \mathrm{L}$ had a greater possibility $(\mathrm{OR}=2.7)$ to have a non mild (moderate-severe) NIHSS, compared to the subjects with CRP concentration below that value. At higher cutoff, subjects with CRP concentration $>25.65$ $\mathrm{mg} / \mathrm{L}$ had a greater possibility $(\mathrm{OR}=17.2)$ to have a severe NIHSS, compared to the subjects with CRP concentration below that value (Table 5). This finding supports the previous studies that showed CRP was involved in the brain damage after ischemia. In an animal study, an ischemic condition that was treated with CRP showed a larger infarct.17 Several in vitro studies showed that CRP could mediate a further inflammation through several mechanisms, such as expression of adhession molecule on endothelial surface and induction of the synthesis of MCP-1,3 induction of the activation of CRP reseptor Fcy CD16/32 on endothelial surface that causes a vasogenic edema,18 and activation of classical complement pathway $(17,18,19)$.

The concentration of MMP-9, a protease activated during ischemia1 $(12,20)$ showed a significant difference between subjects with severe and subjects with non severe (mild-moderate) NIHSS. The median concentration of MMP-9 was significantly higher in subjects with severe NIHSS than the median concentration in the subjects with mild or moderate NIHSS (Table 2, Figure 1). This was in accordance with a report that there was a significant difference of MMP-9 concentration between patients with good and poor outcome (5). The concentration of MMP9 was significantly higher in patients that eventually experienced a massive edema $(\mathrm{p}<0.001)(21)$.

Although no significant correlation was found between MMP-9 level and the severity of discharged NIHSS, the bivariate analysis showed that MMP-9 with concentration greater than or equal to $>1323.84$ $\mathrm{ng} / \mathrm{mL}$ had a greater possibility (18.1 times) to have a severe NIHSS, compared to the subjects with MMP9 concentration below that value (Table 5). This was probably due to the small number of subjects with severe NIHSS at discharge $(3.5 \%)$. An accurate association of MMP-9 should be confirmed by involving more subjects with severe discharged NIHSS.

\section{Conclusion}

The concentration of CRP and MMP-9 at 48-72 hours after the stroke onset were associated with the severity of ischemic stroke based on NIHSS at discharge.

\section{Acknowledgements:}

We thank the Prodia Education and Research Institute for funding this research.

\section{References:}

1. Benakis C, Hirt L, Du Pasquier R. Inflammation and stroke. Kardiovaskulare Medizine. 2009; 12: 143-50.

2. Lakhan EL, Kirchgessner A, Hofer M. Inflammatory mechanisms in ischemic stroke: theraupetic approaches. J Transl Med. 2009; 7: 97-107.

3. Yeh, E.T. CRP as a mediator of disease. Circulation. 2004; 109: II-11-14.

4. Elkind MSV, Tai W, Coates K, Paik MC, Sacco RL. Highsensitive C-reactive protein, lipoprotein-associated phospholipase A2, and outcome after ischemic stroke. Arch Intern Med. 2006; 166: 2073-80.

5. Whiteley W, Wei LC, Sengupta A, Sandercock P. Blood markers for the prognosis of ischemic stroke: a systematic review. Stroke. 2009; 40: e380-9.

6. Rosenberg, G.A. Matrix metalloproteinase and proteolytic opening of the blood brain-barrier in neuroinflamation. In: deVries E, Prat A, editors. The blood-brain barrier and its microenvironment basic physiology to neurological disease. New York: Taylor and Francis Group; 2005. p. 335-58.

7. Saenger AK, Christenson RH. Stroke biomarkers: progress and challenges for diagnosis, prognosis, differentiation, and treatment. Clin Chem. 2010; 56: 21-33.

8. Lynch JR, Blessing R, White WD, Grocott HP, Newman MF, Laskowitz DT. Novel diagnostic test for acute stroke. Stroke. 2004; 35: 57-63. 
9. Reynolds MA, Kirchick HJ, Dahlen JR, Anderberg JM, McPherson PH, Nakamura KK, et al. Early biomarkers of stroke. Clin Chem. 2003; 49: 1733-9.

10. Endres M, Dirnagil U, Moskowitz MA. The ischemic cascade and mediators of ischemic injury. 2009. In: Fisher M, editor. Handbook of clinical neurology, vol 92 (3rd series) Stroke. Part I. Boston: Elsevier; 2009. p. 31-41

11. Graham SH, Hickey RW. Molecular pathophysiology of stroke. In: Davis KL, Charney D, Coyle JT, Nemeroff C, editors. Neuropsychopharmacology: the fifth generation of progress. Pennsylvania: American College of Neuropsychopharmacology. 2002. p. 1317-26

12. Jin R, Yang G, Li G. Inflammatory mechanisms in ischemic stroke: role of inflammatory cells. J. Leukoc. Biol. 2010; 87: $779-80$.

13. Garden GA, Moller T. Microglia biology in health and disease. J Neuroimmune Pharmacol. 2006; 1: 127-37.

14. D'Ambrosio AL, Pinsky DJ, Connolly ES. The role of complement in ischemia/reperfusion injury: implications for neuroprotection. Mol Med. 2001; 7: 367-82.

15. Muir KW, Weir CJ, Alwan W, Squire IB, Lees KR. C-reactive protein and outcome after ischemic stroke. Stroke. 1999: 30: 981-5.
16. Di Napoli M, Papa F, Bocola V. Prognostic influence of increased C-reactive protein and fibrinogen levels in ischemic stroke. Stroke. 2001: 32: 133-8.

17. Di Nappoli M, Schwaninger M, Capelli R, Ceccarelli E, Gianfilippo GD, Donati C, et al. Evaluation of C-reactive protein measurement for assessing the risk and prognosis in ischemic stroke: a statement for health care professionals from the CRP pooling project members. Stroke. 2005; 36: 1316-29.

18. Kuhlmann CRW, Librizzi L, Closhen D, Pflanzner T, Lessmann $\mathrm{V}$, Pietrzik CU, et al. Mechanisms of C-reactive proteininduced blood-brain barrier disruption. Stroke. 2009; 40: 1458- 66 .

19. Mold C, Du Clos TW, C-reactive protein increases cytokine responses to Streptococcus pneumoniae through interactions with Fc\{gamma\} receptors. J. Immunol. 2006; 176: 7598-604.

20. Zhao BQ, Tejima E, Lo EH. Neurovascular proteases in brain injury, haemorrhage and remodeling after stroke. Stroke. 2007; 38: 748-52.

21. Serena J, Blanco M, Castellanos M, Silva Y, Vivancos J, Moro $M A$, et al. The prediction of malignant cerebral infarction by molecular brain barrier disruption markers. Stroke. 2005; 36: 1921-6. 